\title{
Serum MiRNA-122 as a Diagnostic Marker in HCV Related Liver Cirrhosis
}

Tahia M. Ahmed ${ }^{1}$, Ebtesam I. Ahmad ${ }^{1}$, Salah E. Ibrahim ${ }^{1}$, Mysaa A.Saeed ${ }^{2}$

${ }^{1}$ Department of Clinical Pathology, Faculty of Medicine, Zagazig University, Egypt.

${ }^{2}$ Department of Tropical Medicine, Faculty of Medicine, Zagazig University, Egypt.

Corresponding Author

Tahia Mohamed Ahmed

Mobile:

00201205249812

E mail:

mohamed_aly901@ya hoo.com

Key words: Mirna-122 and Liver Cirrhosis
Background and study aim: The miRNA-122 levels decreased with MicroRNAs were evaluated as biomarkers for liver injury in various liver diseases. This study aimed to evaluate the serum miRNA-122 as a potential biomarker for diagnosis and monitoring different stages of disease in chronic hepatitis $\mathrm{C}$ patients.

Patients and Methods: A case-control study included 45 subjects, divided into three groups: control group, compensated, and decompensated cirrhotic patients groups. All participants were subjected to full history taking, clinical assessment, routine lab investigations, hepatitis $\mathrm{B}$ surface antigen, HCV antibodies, HCVRNA using PCR, and determination of serum expression of miRNA-122 using real-time PCR.

Results: The miRNA-122 expression levels among the two groups with liver disease were significantly higher than the control group. Among cirrhotic patients, the expression levels were significantly higher in the compensated subjects compared to the decompensated group.

\section{INTRODUCTION}

Hepatitis $\mathrm{C}$ is a global health problem. Approximately 130-200 million individuals are chronically infected with the hepatitis $\mathrm{C}$ virus (HCV) [1]. Hepatitis $\mathrm{C}$ virus infection can cause acute hepatitis $\mathrm{C}$; following acute infection, $50-80 \%$ of patients develop chronic hepatitis $\mathrm{C}$ which can trigger a chronic inflammatory disease process that might lead to liver fibrosis, cirrhosis, hepatocellular carcinoma, and death [2]. Consequently, the early diagnosis of chronic viral hepatitis plays an important role in hepatitis treatment and prevention, inhibits disease progression, and reduces transmission to others [3]. the progression of liver disease (from Child-Pugh class A to C) but without significant difference. Patients with ascites had a significantly lower expression of miR-122 compared to those without ascites. Patients with gastrointestinal bleeding and hepatic encephalopathy had statistically insignificant lower expression of miRNA 122 compared to subjects without these complications. As regards all patients groups there were significant positive correlations between miRNA-122 expression and (AST, ALT, albumin, and viral load) and a significant negative correlation as regard INR.

Conclusion: $\quad$ Serum miRNA-122 expression levels decreased with the progression of liver disease and at a cutoff value $\leq 2.74$ fold change could predict the occurrence of hepatic decompensation. So Serum miRNA-122 seems to be a useful new diagnostic marker in hepatitis $\mathrm{C}$ patients with different stages of the disease.

Novel biomarkers, such as microRNAs (miRNAs), are being investigated for their diagnostic potential in viral hepatitis, hepatic fibrosis, and hepatocellular carcinoma. MicroRNAs are small non-coding RNAs consisting of 20 25 nucleotides that modify gene expression in plants and animals. Most miRNAs negatively regulate translation through the interaction with the 3 ' untranslated region (UTR) of mRNA in a sequence-specific manner [4].

MiRNA-122 is the most abundant liver-specific microRNA, accounting for approximately $70 \%$ of the total microRNA population in normal adult hepatocytes with approximately 
66000 copies per cell - and is important to the stability and propagation of HCV RNA [5]. MiRNA-122 regulates many genes in the liver that adjust the cell cycle, differentiation, proliferation, and apoptosis [6]. The change in miRNA-122 levels in the blood is a well-known indicator of liver disease and is prominent early before the increase in liver aminotransferase activity, making it a preferable indicator for liver disease - which suggests that miRNA -122 can be a predictive and reliable blood marker for alcohol,viral, and chemical-induced injury of the liver [7]. This study aimed to evaluate the serum miRNA-122 as a potential biomarker for the diagnosis and monitoring of different disease in chronic hepatitis $\mathrm{C}$ patients.

\section{SUBJECT AND METHODS}

\section{Study design:}

A case-control study of 45 adult subjects at the Tropical and Clinical Pathology Departments, Zagazig University Hospitals, between October 2017 and February 2019. Informed written consents were obtained from all subjects (or their guardians) to use their samples and clinical data in this study according to the Declaration of Helsinki.

Subjects were divided into 3 groups:

- Group (1): 15 healthy adult subjects (control group).

- Group (2): 15 patients with HCV related compensated cirrhosis.

- Group (3): 15 patients with HCV related decompensated cirrhosis with symptomatic complications including jaundice, ascites, variceal hemorrhage, or hepatic encephalopathy.

For all subjects, the following procedures were undertaken:

1) Thorough history taking

2) Detailed clinical examination

3) Laboratory investigations:

a) Liver and kidney functions tests: using automated analyzer "Cobas8000-c702" supplied by Roche Diagnostics (Germany).

b) Complete blood count (CBC): using automated cell counter "Sysmex XS" Corporation (Japan). c) Alpha-fetoprotein: using automated analyzer "Cobas8000-c702" supplied by Roche Diagnostics (Germany).

d) Hepatitis markers: HCV antibody and hepatitis B surface antigen using automated analyzer "Cobas8000-c702" supplied by Roche Diagnostics (Germany).

e) Prothrombin time (PT) and International Normalized Ratio (INR): using Sysmex CS 2100 coagulometer supplied by Sysmex, Japan.

f) Quantitative PCR for HCV-RNA: for cases with positive $\mathrm{HCV}$ antibodies.

1. The Child-Pugh scoring system: was estimated for all patients [8].

2. Radiological studies: all patients were submitted to ultrasound examination for assessment of cirrhosis, ascites, and exclusion of focal lesions

3. Special research test: Serum miRNA- 122 expression was analyzed for all subjects in the study using real-time quantitative polymerase chain reaction (RT-PCR). Micro-RNA was extracted from serum using the "miRNeasy Mini Kit" (Qiagen, Germany), then reverse transcription was done using the "miScript II RT Kit" (Qiagen, Germany). Amplification was done using target-specific miScript Primer Assays (forward primers) and the miScript SYBR Green PCR Kit, which contains the miScript Universal Primer (reverse primer) and "QuantiTect SYBR Green PCR Master Mix" (Qiagen, Germany). Real-time PCR was done on the "Stratagene Mx3005P" platform (Agilent Technologies, USA). All steps were done according to manufacturer recommendations. Threshold cycle (CT) values were registered for each sample well and were normalized against the housekeeping gene RNU-6. Fold changes of miRNA expression were calculated using $2^{\wedge-\Delta \triangle \mathrm{CT}}$ method[9], where:

Fold Change $=2^{\wedge-\Delta \Delta \mathrm{CT}}$

$$
\begin{aligned}
& \Delta \Delta \mathrm{C}_{\mathrm{T}}=\Delta \mathrm{CT}_{\text {patients }}-\Delta \mathrm{CT}_{\text {control }} \\
& \left.\Delta \mathrm{C}_{\mathrm{T}} \text { (relative expression }\right)= \\
& \mathrm{CT} \mathrm{T}_{\text {miRNA of interest }}-\mathrm{CT}_{\text {housekeeping RNA }}
\end{aligned}
$$

\section{Statistical Analysis:}

All data were collected, tabulated, and statistically analyzed using SPSS 20.0 for windows (SPSS Inc., Chicago, IL, USA). 
Qualitative data were expressed as frequencies and relative percentages. Chi square test $(\chi 2)$ was used to calculate difference between qualitative variables as indicated. Quantitative data were expressed as mean $\pm \mathrm{SD}$ using ANOVA F-test, Student's t-test, Mann Whitney U test, and Kruskal Wallis test. The Spearman's rank correlation coefficient was used to ascertain the linear correlation. Receiver operating characteristic (ROC) curve was used to evaluate the validity of serum miRNA 122 levels in predicting hepatic decompensation among the cirrhotic patients. All statistical comparisons were conducted with significance level of $\mathrm{P}$ value $\leq 0.05$ indicates significant, $p<0.001$ indicates highly significant difference while, $\mathrm{P}>0.05$ indicates Non-significant difference.

\section{RESULTS}

The demographic data of the studied population are presented in (Table 1). There was no statistically significant difference between the three studied groups regarding age and sex (Pvalue $>0.05$ ).

The frequency of Child-Pugh classes that used for the assessment of disease severity among Patients' groups showed that all compensated cirrhotic patients were a Child-Pugh class A (100\%), while the de-compensated group 2 patients $(13.3 \%)$ were class A, 4 patients $(26.7 \%)$ were class B and 9 patients (60\%) were class C with out statistically significant difference among decompensated patients (Table -2).

The laboratory parameters among the three studied groups are presented in Table 3 with no significant statistical difference between the three studied groups as regards WBCs. The decompensated group showed a significant statistical increase of (AST, T. Bilirubin, D. Bilirubin, creatinine, and INR $(\mathrm{p}=0.0001$, $0.0001,0.0001,0.0001,0.001)$ respectively and a significant statistical decrease of (hemoglobin, platelets, ALT, albumin and total protein $(\mathrm{p}=0.0001)$ in comparison to both compensated and control groups. Using LSD to find the comparison between the three studied groups there was a statistically significant decrease in albumin and total protein, moreover, a significant statistical elevation in T. Bilirubin, D. Bilirubin, creatinine, and INR among Group III compared to group I and II, but there was no significant statistical difference between group I and II.
While significant statistical differences were found between all Groups as regard platelets, ALT and AST (Table- 3).

Concerning the comparison of HCV viral load among Patients' groups there was no statistically significant difference between the two groups (p>0.05) (Table-4).

The miRNA-122 expression levels among the three studied groups showed a statistical significant elevation in miRNA-122 expression levels among the compensated group compared to the control and decompensated groups $(\mathrm{p}=$ 0.0001). On the other hand, there was a significant elevation in miRNA-122 expression levels in the decompensated group compared to the control group $(\mathrm{p}<0.05)$. Using LSD to find the comparison between the three studied groups there were statistically significant differences between all groups as regard miRNA-122 expression levels (Table- 5, Fig 1).

Concerning the relation between miRNA-122 expression and clinical findings among the decompensated group, there was a significantly lower expression of serum miRNA-122 levels in patients with ascites than patients without ascites. Furthermore, serum miRNA-122 expression levels showed no significant differences among patients with and without gastrointestinal bleeding and different grades of hepatic encephalopathy (Table- 6).

Mirna-122 expression level among the decompensated group as regard Child-Pugh classes showed that the lowest serum miRNA122 expression level was in child-pugh class C with no statistically significant difference between the 3 classes using the Kruskal-Wallis non-parametric test ( $\mathrm{p}>0.05)$ (Table -7).

Regarding the correlation between miRNA-122 expression levels and laboratory data among all patients' groups, there were highly significant positive correlations between miRNA-122 expression levels on one hand and AST, ALT, albumin, and viral load on the other hand $(\mathrm{p}=0.047,0.001,0.0001, \quad 0.048)$ respectively. Furthermore, there was a significant negative correlation as regard INR $(\mathrm{p}=0.0001)$ (Figure -2).

The diagnostic power of the studied diagnostic marker (miRNA-122) was investigated using the ROC curve for analysis of fold change values of patients' groups (Figure-3). Mirna-122 at a cutoff value $\leq 2.74$ fold change has proved highly statistically significant performance in prediction 
of occurrence of hepatic decompensation with an specificity of (93.3\%) (Table -8). AUC of 0.987 , the sensitivity of $(100 \%)$ and

Table (1): Demographic data of the studied population.

\begin{tabular}{|c|c|c|c|c|c|c|c|c|}
\hline \multirow[b]{2}{*}{ Parameter } & \multicolumn{6}{|c|}{ Studied groups } & \multirow[b]{2}{*}{$\mathrm{F}$} & \multirow[b]{2}{*}{$\mathrm{P}$} \\
\hline & \multicolumn{2}{|c|}{$\begin{array}{c}\text { Group I } \\
(\text { control) } \\
(\mathrm{n}=15)\end{array}$} & \multicolumn{2}{|c|}{$\begin{array}{c}\text { Group II } \\
\text { compensated cases } \\
(\mathrm{n}=15)\end{array}$} & \multicolumn{2}{|c|}{$\begin{array}{c}\text { Group III } \\
\text { de-compensated cases } \\
(\mathrm{n}=15)\end{array}$} & & \\
\hline $\begin{array}{l}\text { Age (years) } \\
\text { Mean } \pm \text { SD } \\
\text { Range }\end{array}$ & \multicolumn{2}{|c|}{$\begin{array}{c}45 \pm 2.3 \\
(40-49)\end{array}$} & \multicolumn{2}{|c|}{$\begin{array}{c}46 \pm 4 \\
(39-55)\end{array}$} & \multicolumn{2}{|c|}{$\begin{array}{c}48.4 \pm 3.7 \\
(41-56) \\
\end{array}$} & 2.9 & $\begin{array}{c}0.06 \\
\mathrm{NS}\end{array}$ \\
\hline & No. & $\%$ & No. & $\%$ & No. & $\%$ & $\chi^{2}$ & $\mathbf{P}$ \\
\hline $\begin{array}{l}\text { Gender } \\
\text { Male } \\
\text { Female }\end{array}$ & $\begin{array}{l}8 \\
7\end{array}$ & $\begin{array}{l}53.5 \\
46.7\end{array}$ & $\begin{array}{c}10 \\
5\end{array}$ & $\begin{array}{l}66.7 \\
33.3\end{array}$ & $\begin{array}{l}9 \\
6\end{array}$ & $\begin{array}{l}60 \\
40\end{array}$ & 0.6 & $\begin{array}{l}0.7 \\
\text { NS }\end{array}$ \\
\hline
\end{tabular}

SD: Stander deviation. $\quad \chi 2$ : Chi-square test. F: ANOVA test. $\quad$ NS: Non-Significant (p>0.05).

Table (2): Comparison of frequency of Child-Pugh classes among Patients' groups.

\begin{tabular}{|c|c|c|c|c|c|c|}
\hline \multirow[b]{2}{*}{ Child-Pugh classes } & \multicolumn{4}{|c|}{ Patients groups } & \multirow{2}{*}{$\begin{array}{c}\text { Test } \\
\chi^{2}\end{array}$} & \multirow{2}{*}{$\begin{array}{c}\text { Significance } \\
\text { p value }\end{array}$} \\
\hline & \multicolumn{2}{|c|}{$\begin{array}{c}\text { compensated } \\
\mathrm{n}=15\end{array}$} & \multicolumn{2}{|c|}{$\begin{array}{c}\text { Decompensated } \\
n=15\end{array}$} & & \\
\hline \multirow[b]{2}{*}{ A } & No & $\%$ & $\overline{\text { No }}$ & $\%$ & \multirow[b]{2}{*}{7.5} & \multirow[b]{2}{*}{$0.023 *$} \\
\hline & 15 & 100 & 2 & 13.3 & & \\
\hline $\mathrm{B}$ & 0 & 0 & 4 & 26.7 & & \\
\hline $\mathrm{C}$ & 0 & 0 & 9 & 60 & & \\
\hline
\end{tabular}

$\chi 2$ : Chi-square test.

*: Significant $(\mathrm{p}<0.05)$ 
Table (3): Comparison of frequency of Child-Pugh classes among Patients' groups.

\begin{tabular}{|c|c|c|c|c|c|c|}
\hline \multirow[b]{2}{*}{ Item } & \multicolumn{3}{|c|}{ Studied groups } & \multirow[b]{2}{*}{ Test } & \multirow[b]{2}{*}{ p-value } & \multirow[b]{2}{*}{ LSD } \\
\hline & $\begin{array}{l}\text { Group I } \\
\text { control } \\
(n=15)\end{array}$ & $\begin{array}{c}\text { Group II } \\
\text { compensated } \\
(n=15)\end{array}$ & $\begin{array}{c}\text { Group III } \\
\text { de-compensated } \\
(\mathrm{n}=15)\end{array}$ & & & \\
\hline $\begin{array}{l}\text { WBCs }\left(\times 10^{9} / \mathrm{L}\right) \\
\text { Mean } \pm \text { SD }\end{array}$ & $6.9 \pm 1.7$ & $6.6 \pm 1.2$ & $7.8 \pm 7.1$ & $\begin{array}{c}F \\
0.29\end{array}$ & $\begin{array}{l}0.75 \\
\mathrm{NS}\end{array}$ & ------- \\
\hline $\begin{array}{l}\text { Hemoglobin }(\mathrm{g} / \mathrm{dl}) \\
\text { Mean } \pm \text { SD }\end{array}$ & $13.6 \pm 1.8$ & $12.1 \pm 0.71$ & $10 \pm 1.9$ & $\begin{array}{c}F \\
21.6\end{array}$ & $0.0001 * *$ & $\begin{array}{l}>0.05 \mathrm{NS}^{1} \\
<0.001 * * 2 \\
<0.001 * * 3\end{array}$ \\
\hline $\begin{array}{l}\text { Platelets }\left(\times 10^{9} / \mathrm{L}\right) \\
\text { Mean } \pm \mathrm{SD}\end{array}$ & $287 \pm 57$ & $190 \pm 48$ & $75 \pm 30.4$ & $\begin{array}{l}\mathrm{F} \\
77\end{array}$ & $0.0001 * *$ & $\begin{array}{l}<0.001 * * 1 \\
<0.001 * * 2 \\
<0.001 * * 3\end{array}$ \\
\hline $\begin{array}{l}\text { AST(IU/L) } \\
\text { Mean } \pm \text { SD }\end{array}$ & $30.6 \pm 5.1$ & $43.6 \pm 18$ & $77 \pm 39$ & $\begin{array}{l}\mathrm{Kw} \\
27.4\end{array}$ & $0.0001 * *$ & $\begin{array}{l}<0.01 * * 1 \\
<0.001 * * 2 \\
<0.001 * * 3\end{array}$ \\
\hline $\begin{array}{l}\text { ALT(IU/L) } \\
\text { Mean } \pm \text { SD }\end{array}$ & $29.7 \pm 7.5$ & $69 \pm 23$ & $49.2 \pm 15$ & $\begin{array}{l}\mathrm{Kw} \\
32.5\end{array}$ & $0.0001 * *$ & $\begin{array}{l}<0.01 * * 1 \\
<0.001 * * 2 \\
<0.001 * * 3 \\
\end{array}$ \\
\hline $\begin{array}{l}\text { Albumin }(\mathrm{g} / \mathrm{dl}) \\
\text { Mean } \pm \mathrm{SD}\end{array}$ & $4.0 \pm 0.19$ & $3.5 \pm 0.46$ & $2.3 \pm 0.55$ & $\begin{array}{c}F \\
69.5\end{array}$ & $0.0001 * *$ & $\begin{array}{l}>0.05 \mathrm{NS}^{1} \\
<0.001 * * 2 \\
<0.001 * * 3\end{array}$ \\
\hline $\begin{array}{l}\text { Total protein }(\mathrm{g} / \mathrm{dl}) \\
\text { Mean } \pm \mathrm{SD}\end{array}$ & $7.5 \pm 0.3$ & $6.8 \pm 0.4$ & $5.1 \pm 0.8$ & $\begin{array}{c}\mathrm{F} \\
20\end{array}$ & $0.0001 * *$ & $\begin{array}{l}>0.05 \mathrm{NS}^{1} \\
<0.001 * * 2 \\
<0.001 * * 3\end{array}$ \\
\hline $\begin{array}{l}\text { Total bilirubin }(\mathrm{mg} / \mathrm{dl}) \\
\text { Mean } \pm \text { SD }\end{array}$ & $0.7 \pm 0.17$ & $0.8 \pm 0.37$ & $2.67 \pm 0.9$ & $\begin{array}{c}F \\
52.25\end{array}$ & $0.0001 * *$ & $\begin{array}{l}>0.05 \mathrm{NS}^{1} \\
<0.001 * * 2 \\
<0.001 * * 3\end{array}$ \\
\hline $\begin{array}{l}\text { Direct } \\
\text { bilirubin }(\mathrm{mg} / \mathrm{dl}) \\
\text { Mean } \pm \mathrm{SD}\end{array}$ & $0.19 \pm 0.09$ & $0.3 \pm 0.12$ & $1.4 \pm 0.6$ & $\begin{array}{c}\mathrm{F} \\
59.2 \\
\end{array}$ & $0.0001 * *$ & $\begin{array}{l}>0.05 \mathrm{NS}^{1} \\
<0.001 * * 2 \\
<0.001 * * 3\end{array}$ \\
\hline $\begin{array}{l}\text { Creatinine }(\mathrm{mg} / \mathrm{dl}) \\
\text { Mean } \pm \mathrm{SD}\end{array}$ & $0.57 \pm 0.15$ & $0.84 \pm 0.11$ & $1.3 \pm 0.6^{\mathbf{a}, \mathbf{c}}$ & $\begin{array}{c}F \\
13.37\end{array}$ & $0.0001 * *$ & $\begin{array}{l}>0.05 \mathrm{NS}^{1} \\
<0.001 * * 2 \\
<0.01 * * 3\end{array}$ \\
\hline $\begin{array}{l}\text { INR } \\
\text { Mean } \pm \text { SD }\end{array}$ & $1.1 \pm 0.1$ & $1.15 \pm 0.47$ & $1.5 \pm 0.3$ & $\begin{array}{l}\mathrm{F} \\
8.8\end{array}$ & $0.001 * *$ & $\begin{array}{c}>0.05 \mathrm{NS}^{1} \\
<0.01 * * 2 \\
<0.05 * 3\end{array}$ \\
\hline
\end{tabular}

Kw: Kruskal Wallis test. F: ANOVA test. LSD: Least significant difference.

P1: Group I versus Group II. P2: Group I versus Group III. P3: Group II versus Group III.

NS: Non-significant $(\mathrm{p}>0.05) . \quad * *$ : Highly significant $(\mathrm{p}<0.01) . \quad *$ : Significant $(\mathrm{p}<0.05)$

Table (4): Comparison of HCV viral load among the patients' groups.

\begin{tabular}{|l|c|c|c|c|}
\hline \multirow{2}{*}{\begin{tabular}{c} 
viral load $\left(\times 10^{6}\right)$ \\
\multicolumn{1}{|c|}{$(\mathrm{IU} / \mathrm{mL})$}
\end{tabular}} & $\begin{array}{c}\text { Compensated } \\
(\mathrm{n}=15)\end{array}$ & $\begin{array}{c}\text { Pecompensated } \\
(\mathrm{n}=15)\end{array}$ & \multirow{2}{*}{ Mw } & $\mathrm{P}$ \\
\cline { 2 - 5 } & $1.395 \pm 1.187$ & $1.412 \pm 0.698$ & 0.54 & 0.62 \\
\hline $\begin{array}{l}\text { Mean } \pm \text { SD } \\
\text { Median }\end{array}$ & 1 & 1.3 & NS \\
\hline
\end{tabular}

SD: Stander deviation.

Mw: Mann-Whitney u test.

NS: Non-significant $(\mathrm{p}>0.05)$ 
Table (5): Comparison of miRNA-122 expression levels among the three studied groups.

\begin{tabular}{|l|c|c|c|c|c|c|}
\hline \multirow{2}{*}{$\begin{array}{l}\text { Micro RNA122 } \\
\text { Fold change }\end{array}$} & $\begin{array}{c}\text { Group I } \\
(\text { control }) \\
(\mathrm{n}=15)\end{array}$ & $\begin{array}{c}\text { Group II } \\
\left(\begin{array}{c}\text { compensated }) \\
(\mathrm{n}=15)\end{array}\right.\end{array}$ & $\begin{array}{c}\text { Group III } \\
(\text { decompensated }) \\
(\mathrm{n}=15)\end{array}$ & \multirow{2}{*}{ Kw } & P & LSD \\
\hline Mean \pm SD & $0.921 \pm 0.548$ & $4.865 \pm 1.42$ & $1.567 \pm 0.178$ & 31.5 & $0.0001^{* *}$ & $\begin{array}{c}<0.001^{* * 1} \\
<0.05^{* 2} \\
<0.001^{* * 3}\end{array}$ \\
\hline
\end{tabular}

P1: Group I versus Group II

P2: control versus Group III

P3: Group II versus Group III
Kw: Kruskal Wallis test

**: Highly significant $(\mathrm{p}<0.01)$

*: $\quad$ Significant $(\mathrm{p}<0.05)$

Table (6): Relation between miRNA-122 expression levels and clinical findings among the decompensated group.

\begin{tabular}{|c|c|c|c|c|c|}
\hline \multirow{2}{*}{\multicolumn{2}{|c|}{ Variable }} & \multicolumn{2}{|c|}{ Micro RNA 122 expression } & \multirow{2}{*}{ Test } & \multirow{2}{*}{ P-value } \\
\hline & & No. & Mean \pm SD & & \\
\hline \multirow{2}{*}{$\begin{array}{l}\text { Gastrointestinal } \\
\text { Bleeding }\end{array}$} & Yes & 6 & $1.4 \pm 0.5$ & \multirow{2}{*}{$\mathrm{t}=0.64$} & \multirow{2}{*}{$0.52 \mathrm{NS}$} \\
\hline & No & 9 & $1.82 \pm 0.9$ & & \\
\hline \multirow{2}{*}{ Ascites } & Yes & 10 & $1.48 \pm 0.32$ & \multirow{2}{*}{$\mathrm{Mw}=2.25$} & \multirow{2}{*}{$0.037^{*}$} \\
\hline & No & 5 & $1.93 \pm 0.37$ & & \\
\hline \multirow{3}{*}{ Encephalopathy } & Grade1 & 9 & $2.24 \pm 1.48$ & \multirow{3}{*}{$\mathrm{Kw}=1.1$} & \multirow{3}{*}{$0.57 \mathrm{NS}$} \\
\hline & Grade II & 4 & $1.67 \pm 0.67$ & & \\
\hline & Grade IV & 2 & $1.37 \pm 0.47$ & & \\
\hline
\end{tabular}

Mw: Mann-Whitney u test. Kw: Kruskal Wallis test. t: t-test. *: Significant $(\mathrm{p}<0.05)$.

NS: Non- significant $(\mathrm{p}>0.05)$.

Table (7): Mirna-122 expression among the decompensated group as regard Child-Pugh classes.

\begin{tabular}{|c|c|c|c|}
\hline \multirow{2}{*}{ Child-Pugh classes } & Micro RNA 122 expression & \multirow{2}{*}{ Test of sig } & \multirow{2}{*}{ p-value } \\
\cline { 2 - 2 } & Mean \pm SD & \multirow{2}{*}{ Kw=5.01 } & \multirow{2}{*}{0.82 NS } \\
\hline A & $2.84 \pm 0.63$ & \\
\hline B & $1.48 \pm 0.6$ & & \\
\hline
\end{tabular}

Kw: Kruskal Wallis test.

NS: Non-significant $(\mathrm{p}>0.05)$.

Table (8): Validity of miRNA-122 for prediction of decompensation in patients' groups..

\begin{tabular}{|l|c|}
\hline \multicolumn{1}{|c|}{ Items } & \\
\hline Area under curve(AUC) & 0.987 \\
\hline 95\% confidence interval(95\%CI) & $0.955-1$ \\
\hline P value & $0.0001 * *$ \\
\hline Optimal cut-off & $\leq 2.74$ \\
\hline Sensitivity\% & $93.3 \%$ \\
\hline Specificity\% & $100 \%$ \\
\hline Predictive value positive & $100 \%$ \\
\hline Predictive value negative & $93.75 \%$ \\
\hline Accuracy & $96.7 \%$ \\
\hline
\end{tabular}

AUC: Area under the curve. $\quad$ CI: Confidence interval. $\quad$ **: Highly significant $(\mathrm{P}<0.01)$. 


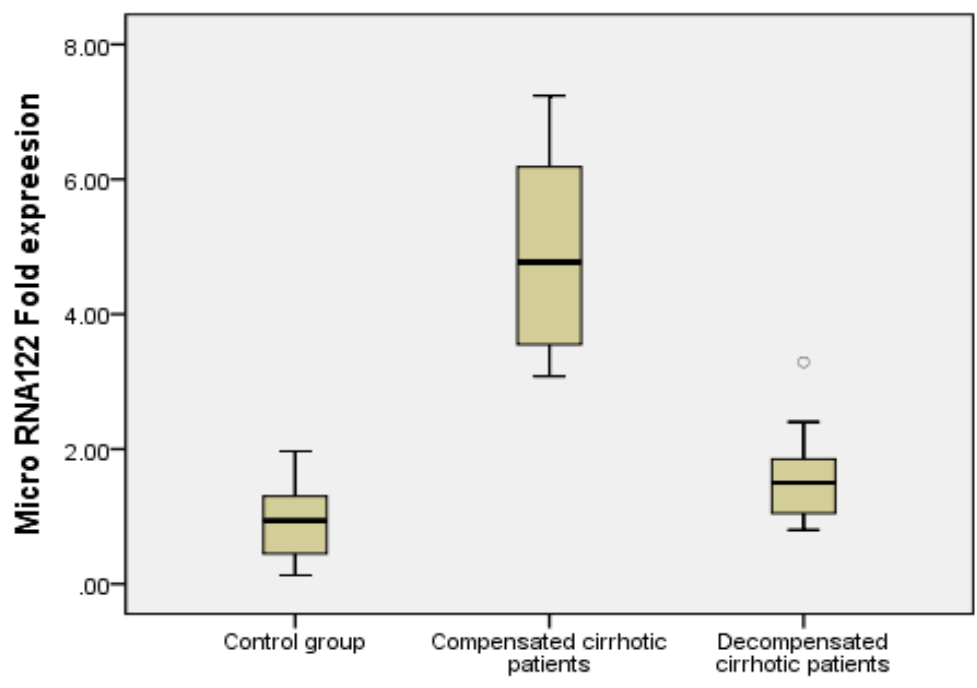

Figure (1): Box-plot showing the comparison of miRNA-122 expression levels among the three studied groups.
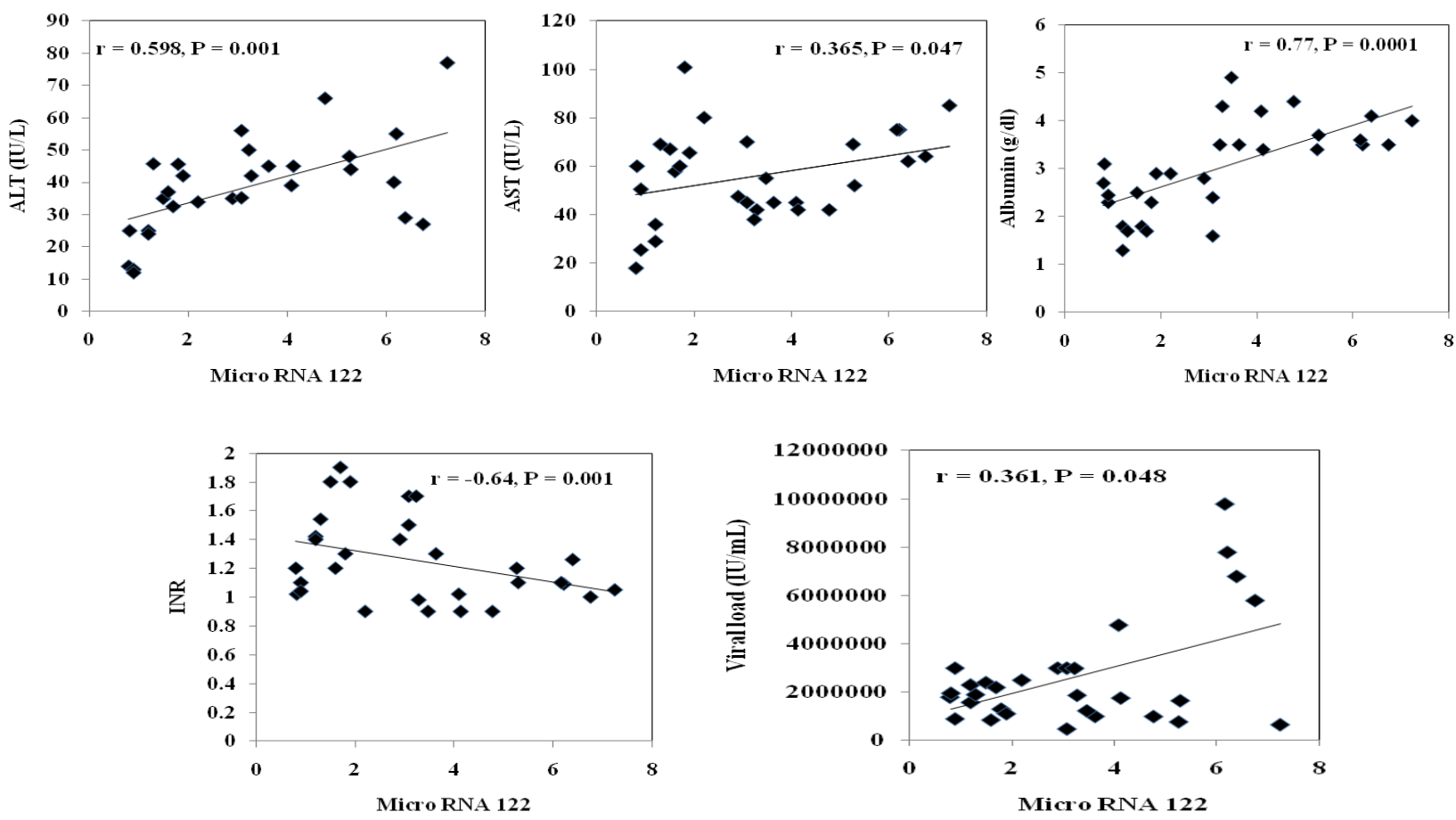

Figure (2): Correlation between miRNA-122 expression and AST, ALT, albumin, INR, and viral load among all cirrhotic patients. 


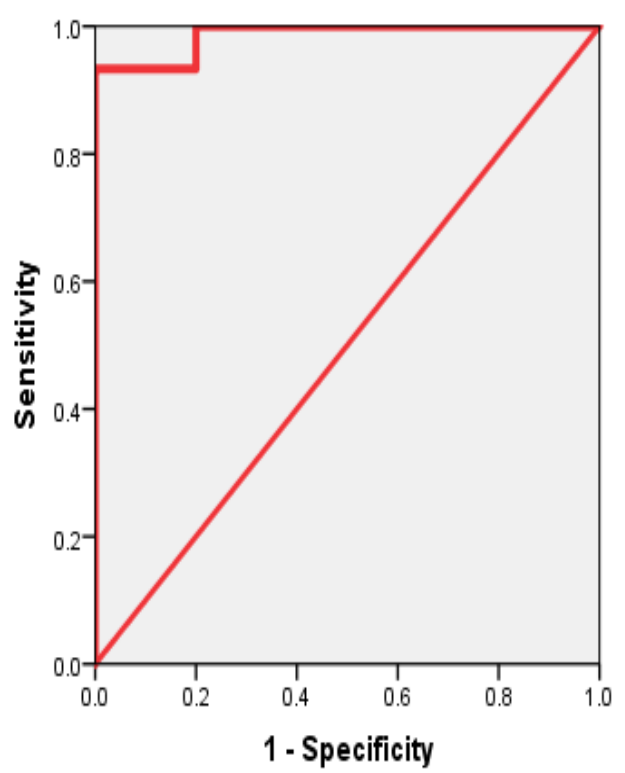

Figure (3): ROC curve for validity of miRNA-122 in prediction of decompensation among the cirrhotic Patients

\section{DISCUSSION}

MiRNA-122 is considered the most abundant miRNA in the liver accounting about $70 \%$ of the total hepatic miRNAs, and a central player in liver development, differentiation, homeostasis and metabolic functions [10]. Its hepatocytespecific early expression in liver injury in addition to its direct interaction with HCV RNA has made it an attractive biomarker in liver disease [11]. The level of miR-122 has been shown to correlate with the stage of infection and severity and is useful in assessing the treatment response [12]. The aim of this study was to evaluate serum miRNA-122 as a potential biomarker for diagnosis and monitoring of the different stages of disease in chronic hepatitis $\mathrm{C}$ patients.

Regarding platelet count, a highly significant decreasing trend was noted among the decompensated group compared to compensated and control groups. This finding is in keeping with that of Kholeif et al [13]. The pathophysiology of thrombocytopenia in hepatitis $\mathrm{C}$ patients is multifactorial with contribution from auto-immunogenicity, direct bone marrow suppression, hypersplenism, decreased thrombopoietin production and therapeutic adverse effects [14].

In concordance with our findings, a recent study reported significantly higher mean ALT titer among the compensated group compared to the other groups, with a significant increasing trend among the decompensated group when compared to the control group. The mean AST level was significantly higher in the decompensated group compared to the other two groups, with a significant increasing trend among the compensated group compared to the control group [13]. These findings are explained by the leakage of ALT and AST from damaged hepatocytes and into the serum where high ALT levels reflect early damage at a subcellular level and AST is a marker of additional mitochondrial or nuclear damage. [15].This study showed that there was a significant positive correlation between miRNA-122 expression levels and aminotransferase levels (ALT, AST) among subjects with liver disease. Consistent with this finding, Kholeif et al., and Waidmann et al., reported that miRNA-122 levels were positively correlated with ALT and necro-inflammatory activity in patients with chronic hepatitis $\mathrm{C}[\mathbf{1 3}$, 16]. This can be attributed to the initial increase in miRNA-122 levels due to inflammation and necrosis of the hepatocytes, followed by a drop with the development of fibrosis [17]. On the other hand, this result disagrees with that of Wang et al., who reported the lack of correlation between serum miRNA-122 and ALT levels or liver injury in chronic hepatitis $C$ patients [18]. The explanation for this disparate finding might be due to use of a different method - results represented by the $\mathrm{Ct}$ value of miR-122 without

Ahmed et al., Afro-Egypt J Infect Endem Dis 2020;10(4):335-345

https://aeji.journals.ekb.eg/

http://mis.zu.edu.eg/ajied/home.aspx 
normalization with internal control, and different sample size.

The miRNA-122 expression levels among the two groups with liver disease were significantly higher than the control group. Among cirrhotic patients, the expression levels were significantly higher in the compensated subjects compared to the decompensated group. These two findings are consistent with those of Shehab-Eldeen et al and El-Guendy et al respectively [11, 19]. In healthy subjects, miRNA-122 is largely confined to hepatocytes with very low circulating levels. With hepatocyte injury, miRNA-122 is released into the circulation more readily with a concomitant rise in serum levels. With the consequent loss of hepatocytes and the progression of fibrosis, the circulating miR-122 levels fall again [20]. In contrast to our findings, El-Garem et al., reported a significant decrease in miRNA-122 levels among 30 cirrhotic patients when compared to normal controls. This variance might be due to the use of different reference genes in determining miRNA-122 levels. Furthermore, most cirrhotic patients studied were classified as Child-Pugh class A \& $\mathrm{B}$ and not by whether they were compensated or not, as in our work [17].

Patients with ascites had a significantly lower expression of miR-122 compared to those without ascites. Patients with gastrointestinal bleeding and hepatic encephalopathy had statistically insignificant lower expression of miRNA 122 compared to subjects without these complications. Sabry et al., and Waidmann et al., affirm that the lower miRNA-122 expressions with more advanced disease are due to the reduced release from hepatocyte and higher volume distribution in patients with ascites [21, 16].

This study showed a lower expression level of miR-122 among the decompensated group with Child-Pugh class $\mathrm{C}$ compared to classes $\mathrm{A}$ and $\mathrm{B}$ (CPC-A and B). This is in agreement with Marquez et al., who demonstrated that the expression levels of miR-122 decreased concomitantly with biochemical evidence of hepatocyte damage, and were significantly low with advanced disease most likely the result of reduced release from hepatocyte[22].

The current study showed a statistical significant positive correlation of miRNA-122 with serum $\mathrm{HCV}$ load, this finding is in agreement with Kumar et al., and Ghoneim et al., who reported a significant positive correlation between miRNA122 level and HCV-RNA load [23,24]. This can be explained by that upon viral infection miRNAs might be passively released from the damaged or dying cells and might be linked to the virus itself, which can also elicit the secretion of miRNAs from host cells to influence the cellular physiology for their production [23].

At a cut-off point of $\leq 2.74$ fold change, the sensitivity and specificity of miRNA-122 in predicting hepatic decompensation in cirrhotic patients was $100.0 \%$ and $93.3 \%$ respectively (AUC $=0.987$, P-value 0.0001). In a similar study, Sabry and colleagues reported sensitivity and specificity values of $100 \%$ and $90.1 \%$ respectively at a cut off value of 0.892 (AUC= 0.942) [21]. This low cut off value can be attributed to a large sample size with 22 patients in the compensated group and 78 in the decompensated group.

Due to constraints in resources, this study had a small sample size as to limit generalization of the findings. The authors recommend larger studies including those utilizing prospective longitudinal designs to clarify the role of serum miRNA-122 as a potential biomarker for early diagnosis of chronic hepatitis $\mathrm{C}$ infected patients.

\section{CONCLUSION}

Serum miRNA-122 expression (at a cut-off of $<2.74$ ) is a promising biomarker for the prediction of hepatic decompensation. As its level decreases with progression of liver disease, serum miRNA-122 expression is a useful diagnostic marker in hepatitis $\mathrm{C}$ patients with different stages of the disease.

\section{Abbreviations:}

HCV: Hepatitis C Virus.

INR: International normalized ratio of prothrombin time.

miRNA: micro RNA.

PCR: Polymerase Chain Reaction.

ROC: Receiver Operating Characteristics.

Ethical approval: all procedures were approved by Zagazig University Institutional Review 
Board (IRB), the ethical committee of Zagazig University Hospitals.

\section{Conflict of Interest: None}

Funding: This study has not received any funds.

\section{REFERENCES}

1. Wei L, Lok AS. Impact of new hepatitis C treatments in different regions of the world. Gastroenterology 2014; 146:1145-50.

2. Elghazaly H, Gaballah A and Eldin NB. Clinicpathological pattern of hepatocellular carcinoma (HCC) in Egypt. Ann Oncol 2018; 29, mdy151. 018.

3. Cuadros DF, Branscum AJ and Miller FD, AbuRaddad LJ. Spatial epidemiology of hepatitis C virus infection in Egypt: Analysis and implication. Hepatology 2014; 60 (4): 1150-59.

4. Bartel D. MicroRNAs: target recognition and regulatory functions. Cell 2009; 136: 215.

5. Henke JI, Goergen D, Zheng J, Song Y, Schüttler CG, Fehr C, et al. microRNA-122 stimulates translation of hepatitis $\mathrm{C}$ virus RNA. EMBO J 2008; 27(24): 3300-3310.

6. Boutz DR, Collins PJ, Suresh U, Lu M, Ramírez $\mathrm{CM}$, Fernández-Hernando $\mathrm{C}$, et al. Two-tiered approach identifies a network of cancer and liver disease-related genes regulated by miR-122. $J$ Biol Chem 2011; 286(20): 18066-18078.

7. Wang $K$, Zhang $S$, Marzolf $B$, Troisch $P$, Brightman A, $\mathrm{Hu} \mathrm{Z}$, et al. Circulating microRNAs, potential biomarkers for druginduced liver injury. PNAS 2009; 106: 4402 doi: 10.1073/pnas.0813371106

8. Cholongitas E, Papatheodoridis GV, Vangeli M, Terreni N, Patch D, Burroughs AK. The model for end-stage liver disease--should it replace Child-Pugh's classification for assessing prognosis in cirrhosis? Alimentary Pharmacology \&Therapeutics 2005; 22 (11-12): 1079-1089.

9. Livak K, Schmittgen T. Analysis of relative gene expression data using real time quantitative PCR and the $2^{\wedge}-\Delta \Delta C T$ method. Methods $2001 ; 25$; 402-8.

10. Chang J, Nicolas E, Marks D, Sander C, Lerro A, Buendia MA, et al. MicroRNA-122, mammalian liver-specific microrna, is processed from hor mRNA and mat downregulate the high affinity cationic amino acid transporter cat-1. RNA Biol 2004; 1: 106.

11. Shehab-Eldeen S, Nada A, Abou-Elela D, ElNaidany S, Arafat E and Omar T. Diagnostic
Performance of microRNA-122 and microRNA224 in Hepatitis C Virus-Induced Hepatocellular Carcinoma (HCC). Asian Pac J Cancer Prev 2019; $20 \quad$ (8): 2515-2522. doi:10.31557/APJCP.2019.20.8.2515

12. Koberle V, Waidmann O, Kronenberger B, Andrei A, Susser S, Füller C, et al. Serum microrna-122 kinetics in patients with chronic hepatitis $\mathrm{c}$ virus infection during antiviral therapy. Journal of viral hepatitis 2013; 20(8): 530-535. doi: 10.1111/jvh.12075.

13. Kholeif H, AboulEla AM, Badawy D. Circulating Micro RNA-122 in Hepatitis C Virus Infected in Egyptian Group of Patients. Clinical Medicine and Diagnostics 2015; 5(6): 114-121.

14. Dahal S, Upadhyay S, Banjade R, Dhakal P, Khanal N, Bhatt VR. Thrombocytopenia in Patients with Chronic Hepatitis C Virus Infection. Mediterr J Hematol Infect Dis 2017; 9(1):e2017019.

15. Aragon G, Younossi ZM. When and how to evaluate mildly elevated liver enzymes in apparently healthy patients. Cleve Clin J Med 2010; 77(3): 195-204.

16. Waidmann V, Köberle F, Brunner S, Zeuzem S, Piiper A, Kronenberger B. Serum MicroRNA122 predicts survival in patients with liver cirrhosis. PLOS ONE 2012; 7(9):e45652. doi: 10.1371/journal.pone.0045652.

17. El-Garem H, Ammer A, Shehab H, Shaker O, Anwer M, El-Akel $\mathrm{W}$, et al. Circulating microRNA, miR-122 and miR-221 signature in Egyptian patients with chronic hepatitis $\mathrm{C}$ related hepatocellular carcinoma. World $J$ Hepatol 2014; 6(11):818-824.

18. Wang J, Jiang D, Rao H, Zhao J, Wang Y, Wei L. Absolute quantification of serum microRNA122 and its correlation with liver inflammation grade and serum alanine aminotransferase in chronic hepatitis $\mathrm{C}$ patients. International Journal of Infectious Diseases 2015; 30: e52e56.

19. El-Guendy NM, Helwa R, El-Halawany MS, Abdel Rahman Ali S, Tantawy Aly M, Hasan Alieldin $\mathrm{N}$, et al. The liver MicroRNA expression profiles associated with chronic hepatitis C virus (HCV) genotype-4 infection: A preliminary study. Hepatitis Monthly 2016;16(4):e33881

20. Amr KS, Atia HA, Elbnhawy RA and Ezzat WM. Early diagnostic evaluation of miR-122 and miR-224 as biomarkers for hepatocellular carcinoma. Genes Dis 2017; 4: 215-21. 19

Ahmed et al., Afro-Egypt J Infect Endem Dis 2020;10(4):335-345

https://aeji.journals.ekb.eg/

http://mis.zu.edu.eg/ajied/home.aspx 
21. Sabry JH, El-Shaer OS, Ahmed IA, Said EM, El Hammady AM, Abdelmoneam AH, et al. Serum MicroRNA-122 as a Prognostic Biomarker in Patients with Liver Cirrhosis. Annals of Applied Bio-Sciences 2016; 3(4):286-295

22. Marquez RT, Bandyopadhyay S, Wendlandt EB, Keck K, Hoffer BA, Icardi MS, et al. Correlation between microRNA Expression Levels and Clinical Parameters Associated with Chronic Hepatitis C Viral Infection in Humans. Laboratory Investigations 2010; 90(12): 1727 1736. doi: 10.1038/labinvest.2010.
23. Kumar S, Chawla Y, Ghosh S, Chakraborti A. Severity of hepatitis C virus (genotype-3) infection positively correlates with circulating microRNA-122 in patients sera. Dis Markers $2014 ; 435-476$.

24. 24. Ghoneim EM, Abed El-Aziz AM, Abd ElMottaleb TM, El-Hendawy GR, El-Ezawy HM and Khalil FO. Profiling of microRNA-122 in chronic hepatitis C. Menoufia Med J 2016;29:826-34 